\title{
Labour
}

Journal of Canadian Labour Studies

Le Travail

Revue d'Études Ouvrières Canadiennes

\section{Sarah Glassford and Amy Shaw, eds., Making the Best of It: Women and Girls of Canada and Newfoundland During the Second World War (Vancouver: University of British Columbia Press 2020)}

\section{Linda Kealey}

Volume 86, automne 2020

URI : https://id.erudit.org/iderudit/1074486ar

DOI : https://doi.org/10.1353/llt.2020.0050

Aller au sommaire du numéro

Éditeur(s)

Canadian Committee on Labour History

ISSN

0700-3862 (imprimé)

1911-4842 (numérique)

Découvrir la revue

Citer ce compte rendu

Kealey, L. (2020). Compte rendu de [Sarah Glassford and Amy Shaw, eds., Making the Best of It: Women and Girls of Canada and Newfoundland During the Second World War (Vancouver: University of British Columbia Press 2020)]. Labour / Le Travail, 86, 200-202. https://doi.org/10.1353/ltt.2020.0050 d'utilisation que vous pouvez consulter en ligne. 
when it comes to race and the disproportion of women of colour in Canadian prisons. Furthermore, it would have been interesting to write the biography of an Indigenous woman to address the ongoing situation of Indigenous women's high incarceration rate in Canadian federal and provincial prisons. Seeing the development of the penitentiary as an instrument not only of industrial capitalism but also of settler colonialism would have allowed McCoy to grasp the "true nature of the beast" and even provide a better light on cases of immigrant women such as the ones he presents. Unruly women are and have been unfit to the settler project throughout the Americas, and many stories remain to be written on their resistance, including in carceral settings.

Nathalie Rech

Université du Québec à Montréal

\section{Sarah Glassford and Amy Shaw, eds., Making the Best of It: Women and Girls of Canada and Newfoundland During the Second World War (Vancouver: University of British Columbia Press 2020)}

This COLLECTION of twelve original essays reprises Glassford and Shaw's earlier collection, A Sisterhood of Sorrowing and Service: Women and Girls of Canada and Newfoundland During the First World War (Vancouver: UBC Press 2012). Framed by a strong introduction and conclusion as well as four section introductions, the editors provide contextual information tying the wars together and a critical approach to the much-debated older fascination with the degree to which war liberated women. While gender is central to the experiences of women and girls, it is not the only or defining identity since various communities structured these experiences, as well as the opportunities that arose and the narratives created. Scholars need to ask 'which women' thus bringing into play age, class, religion, ethnicity, race and language among other factors.

Four essays on women, children and war comprise the first section. Childhood memories of the war are explored through the history of emotions by Barbara Lorenzkowski. Drawing on oral histories of sixteen women who grew up in Halifax and Saint John, she analyses children's "place-based emotional practices and experiences," (36) mindful of the effect of memory on her interviewees. Within families, neighborhoods and cities girls learned about war partly through emotions. Friendships formed and some lasted a lifetime. Young women met servicemen who often became part of the family as well as dance partners in chaperoned social settings, thus complicating the notion of servicemen's predatory behavior. Friendship was also key for British children evacuated to Canada, the subject of Claire Halstead's chapter which eschews oral history, preferring evidence from letters and memoirs written during the war. Canadian girls and women contributed to the war effort by welcoming "war guests" into their homes either through a private scheme or through the British government's Children's Overseas Reception Board. Parents used the terminology of friendship referring to Canada as a sister country bound by Commonwealth ties.

Lisa Moore's chapter examining three elite private schools for young women in Montreal fills a gap in our knowledge about adolescent experiences of the war in that province. There are few surprises here: English-speaking Protestant girls embraced the war effort while Francophone girls in a teacher training school and attending a mixed (French and English language) boarding school 
did not, thus reflecting the FrenchEnglish divide over participation in the war. Early childhood education and childcare during the war are the subjects of Lisa Pasolli's contribution. She examines the federal Wartime Day Nurseries Act which provided some women workers with childcare from 1942-46 and led to important developments in kindergarten and pre-school education. Usually framed as a temporary measure to get women into the labour force, Pasolli convincingly argues that "this remarkable policy experiment simply reinforced the disconnect between women's and children's rights in the Canadian state." (85)

Part two features three chapters on the home front. Jennifer Shaw's chapter uses oral history to explore the activities of Jewish women who undertook war work particularly under the umbrella of the Canadian Jewish Congress. Life on the home front was shaped not only by gender but also by faith and culture which sometimes resulted in tensions between patriotic and cultural expectations. The other two chapters, both by male authors, delve into the role of consumer culture in wartime. Graham Broad's chapter explores the popular image of rationing, scrap metal collecting and victory gardens, arguing that consumer restraint occurred only later in the war. As more people joined the paid labour force, consumer spending and savings increased over the course of the conflict. As noted by Broad and Joseph Tohill, middle-class Mrs. Consumer played a key role in shopping to win the war and later in taking a limited role in advising on, and policing, economic activities including rationing and pricing under the auspices of the Consumer Branch of the War Time Prices and Trade Board. Led by Byrne Hope Sanders and women of privilege, the Consumer Branch worked to block the demands of organized labour and radical consumer groups and resisted increased roles for women and consumers in policy making, according to Tohill.

Part three features women's war work in the Mennonite Central Committee and the Canadian Red Cross Corps (CRCC); both provided rare overseas opportunities for civilian women to engage in humanitarian aid. Marlene Epp's chapter suggests that Mennonite women developed an active resistance to war by providing material and moral relief to those suffering from violence, including those who staffed hospitals and evacuation centres abroad during and after the war. Sarah Glassford's chapter, like Lorenzkowsi's, adopts a history of emotions framework to emphasize the importance of kinship, friendship and nationality in understanding how women coped with war and assisted men to cope as well. Both Epp and Glassford use diaries and letters to examine how these organizations contributed to psychological as well as physical resilience in their overseas operations. In the case of the CRCC, women filled a volunteer labour shortage in the UK acting as transport drivers, office staff and food administrators as well as nurses from 1942 to 1947. While acknowledging the friendship bonds women formed with servicemen, Glassford also tackles the less positive aspects of harassment, sexual assault and a dramatic rise in extramarital sex, though unfortunately no direct statistical evidence is cited.

The final section, Part four, tackles subjects that have received previous scholarly attention: nursing, women's entry into non-traditional work and into the armed forces. Heidi Coombs' chapter focuses on nursing in Labrador, the only piece in the collection highlighting Newfoundland and Labrador. Very little has been written on Labrador during World War II, so this is a welcome addition. Medical care fell 
under the auspices of the International Grenfell Association (IGA, originally the Grenfell Mission which started in 1892). War made it difficult for the IGA to retain or recruit staff and obtain supplies. As Coombs shows, the deaths and retirements of physicians transformed the roles of 52 nurses who had to assume the doctors' duties of diagnosing and treating all the patients, thus making the nurse "the backbone of this Mission." (214)

Sarah Hogenbirk's chapter looks at ordinary servicewomen's deaths and the need for a more inclusive remembrance. Defense officials appear to have been hesitant to recognize and report women's deaths; at least in this group of 91 who were mostly cooks and clerks. By choosing to eliminate professionals such as nurses and doctors, the author's conclusions remain limited.

One of the most interesting chapters in this volume digs into the messages and imagery aimed at women who worked in industry. Sarah Van Vugt dissects the iconic images of the woman war worker whose uniform, safety equipment and hair covering threatened to transform the female body and undermine her femininity. Using newsletters from three Southern Ontario war plants, the author demonstrates how management encouraged women workers to participate in beauty culture sessions and fashion shows. Tensions arose over hair coverings as women sought to exert some control over their appearance in spite of safety concerns. While managers wanted to attract women to factory work, they also regarded women as distracting to men thus creating 'gendered risks' on the factory floor. (252)

Shaw and Glassford's collection demonstrates the importance of listening to women's voices and asking new questions. This volume helps us move away from the old debate of whether (and how) women are liberated (or not) by the exigencies of conflict and suggests that their experiences were multi-faceted. Making the Best of It is a welcome addition to "Studies in Canadian Military History."

Linda KeAley

University of New Brunswick

\section{Julie Guard, Radical Housewives: Price Wars \& Food Politics in Mid-Twentieth Century Canada (Toronto: UTP 2019)}

In RADICAL HouseWIVES, Julie Guard has written not just the definitive history of Housewives Consumer Association, but of mid-century Left consumer activism in Canada more broadly.

The Housewives, for those unfamiliar, started as a grassroots movement of mostly social democratic and communist women pushing for greater state control over the price and distribution of food and other necessities during the late 1930s. While their campaigns in Toronto, in particular, met with some success during these early years, they emerged as a truly national organization during the war and early postwar years as their message of greater state control over the economy found broader popular appeal across the political spectrum. At the peak of their influence in the early postwar years they claimed tens of thousands of members and dozens of branches across the country.

Guard's study focuses, particularly, on the rise and fall of maternalism as a viable political strategy for the Left during the 1930s and 1940s. It was a strategy, she argues, that shielded the Housewives from accusations of communist infiltration during its formative years but proved to be part of its undoing during the rabid anticommunism of the Cold War. It is also a strategy, she argues, that saw the Housewives go effectively ignored by generations of left and labour historians. 